\title{
The Presentation of the Political Transition in the Early 1990s in Albania in the History Textbooks of Primary and Secondary Education
}

\author{
Prof. Ass. Dr. Esilda Luku \\ Faculty of Political Sciences and Law, "Aleksandër Moisiu" University, Durrës \\ Email: esildaluku@yahoo.com
}

\section{Doi:10.5901/ajis.2016.v5n3s1p511}

\section{Abstract}

\begin{abstract}
This paper aims to analyse the political system change in Albania, in the early '90s, as presented in the history textbooks for primary and secondary school. In regard to the chronological criteria, as the main principle of historicism, the overthrow of the communist regime and the establishment of democracy appear as a symbiosis of the internal situation and the pressure of the international community. The Albanian government due to the economic hardship, the social backwardness and the political tensions was gradually losing its ruling legitimacy on the basis of Marxist-Leninist ideology. The fallacy of the party-state propaganda caused a general dissatisfaction that led to the organization of anti-communist demonstrations, which culminated with the Student Movement of December 1990 and the institutionalisation of political pluralism, with the formation of the first opposition political party, the Democratic Party. The successive democratic transformations up to the creation of Aleksander Meksi's government, after the elections of 22 March 1992, were as a result of the effect domino, too. The democratic revolutions in the Eastern countries and the influence of the international actors favoured the democratic changes in Albania. The theoretical and empirical analysis of the process of political transition in the history textbooks of elementary and secondary education in Albania, based on the historical discourse analysis, it is important not only for the political turnaround that marks this period of history in the way of building democratic institutions, creating a market economy and the functioning of civil society, but in particular for the challenge of educating young people as worthy citizens of a society that aspires to integrate into the European family.
\end{abstract}

Keywords: communist legacy, the Student Movement, change of political system, textbooks, discourse analysis

\section{Introduction}

"History is not a package of knowledge which can be handed over to new generations, but a continuous dialogue between understanding the present, interpreting the past and having expectations for the future" (Minoski, 2001: 163). This phrase highlights the fact that "the school textbook not only serves to impart knowledge to pupils, but also to cultivate attitudes and transmit values and models of behaviour associated with the emotional side of the personality and thus influencing the views, convictions and choices, as well as the behaviour of the individuals" (Balkan Colleges Foundation, 1998: 11).

It is generally acknowledged that "history textbooks are the classical objects of history didactics research. They are still the dominant translation of the curriculum in schools and they continue to constitute the most widely used resource for teaching and learning, despite the development of new media and educational technologies" (Repoussi \& TutiauxGuillon, 2010: 156). They are often regarded as the key instructional materials to shape collective memory and foster social cohesion (History education, 2013). But, most of the Albanian history textbooks suffer from the pure, one-sided factography, which has two negative dimensions: "a) the historical events are interpreted only from one position, rarely or never opening the question of the "other sided", which does not contribute to a rational, critical evaluation of the historical processes and, b) the textbooks devote very little, or no space, for the presentation of some more general, common, present values, using the historical events as illustrations. This prevents the teaching of history from being a valuable source for political socialization" (Simoska, 2001: 98).

\section{A Quantitative Observation of the Albanian Democratic Transition in History Textbooks}

The period of democratic transformations in Albania, in the early 90 s, occupies an important place in the content of history textbooks of primary and secondary education. The fall of the socialist regime and the victory of the democratic system marked the historic turn in the political, economic and socio-cultural development of the Albanian society, oriented 
towards the most successful achievements of the western states. Therefore, the treatment of the political transition in the history textbooks aimed at serving the historical knowledge and "preparing the future citizen as an active member of the historical perspective of a democratic society" (Kuri \& Gjini, 2008: 81).

In the curriculum of history of middle and high schools, general or profiled, it is applied the scientific criteria of periodization of history, which relies on the establishment of a fair report on the examination of various historical periods (Xhelili, 2001: 30). Until 2005, when the primary and secondary education used the same history textbooks, in a national level, the coverage of the political changes in Albania concluded with the legalization of political pluralism. Specifically, in the book "History of the Albanian people 8", published in Tirana, 2002, with a total of 18 chapters, the political transition is treated only in Chapter XVII entitled: "The collapse of the socialist system (1980-1990)", pp. 213-221, in the two following lessons: 17.1 "The beginning of the crisis and its expansion" and 17.2 "The political pluralism in Albania" (Korkuti, et.al., 2002). Also, in the textbook "The history of the Albanian people, for the fourth grade of high general school", published by the School Publishing House, in 1999, one of 22 chapters is dedicated to the democratic changes in Albania, as follows: Chapter XXI - Theme 21.1 "The crisis and the collapse of the political system in Albania", pp. 318-323 and Theme 21.2 "The anti-communist movement and the institutionalisation of the political pluralism", pp. 321-323 (Korkuti, et.al., 1999).

But due to the altered text reform, in the history curriculum is included even an analysis of the Albanian democratic state building and its performance in the Euro-Atlantic integration. For instance, in the book of the authors Bernard Zotaj and Maringlen Kasmi "History of the Albanian people, for the ninth grade of the 9-years school", the democratic developments in Albania are presented in Chapter XIV, respectively in Topic 14.1: "The Fall of communist regime. The victory of the Democratic Revolution", pp. 141-142, and Topic 14.2: "Albania from 1992 to 2000", pp.143-144 (Zotaj \& Kasmi, 2012). Whereas the text "History of Albanians 12: for the twelfth grade of the high school", published by Uegen, 2011, with 8 chapters in total, the post-communist period covers these issues: Theme 8.1: "The movement of December 1990 and the first stages of democracy", pp. 151-153; Theme 8.2 "Establishing the rule of law and market economy", pp. 154-156 and Theme 8.3: "The challenges of Albanian democracy", pp. 157-159 (Meta et. al., 2011).

In more detail, the place that the democratic transition in Albania occupies in the 13 history textbooks of primary and secondary education, taken into consideration, appears in the table and the chart below:

Table 1:

\begin{tabular}{|c|c|c|c|c|c|c|c|}
\hline No. 7 & The authors & Title of the textbook & $\begin{array}{c}\text { Year of } \\
\text { publication }\end{array}$ & $\begin{array}{c}\text { No. of } \\
\text { chapters }\end{array}$ & $\begin{array}{l}\text { Total no. } \\
\text { of } \\
\text { lessons }\end{array}$ & $\begin{array}{l}\text { No. of lessons dedicated } \\
\text { to the political transition } \\
\text { in Albania }\end{array}$ & $\underset{\%}{\text { Volume in }}$ \\
\hline 1 & $\begin{array}{l}\text { Myzafer Korkuti, Petrika Thëngjilli, Gazmend } \\
\text { Shpuza, Fatmira Rama, Xhelal Gjeçovi, Ajet } \\
\text { Shahu, Ana Lalaj }\end{array}$ & History of Albanian people 8 & 2002 & 18 & 58 & 2 & $3 \%$ \\
\hline $2 \mid 1$ & Myzafer Korkuti, Xhelal Gjeçovi, Agron Gani & $\begin{array}{l}\text { History 9: for the ninth grade of the nine } \\
\text { years school }\end{array}$ & 2008 & 14 & 58 & 2 & $3 \%$ \\
\hline 3 & $\begin{array}{l}\text { Prof.dr. Beqir Meta, Prof. dr. Muharrem Dezhgiu, } \\
\text { Ma. Bedri Kola, Xhevair Lleshi }\end{array}$ & $\begin{array}{l}\text { History of Albanian people: for the ninth } \\
\text { grade of the nine years school }\end{array}$ & 2008 & 14 & 57 & 2 & $4 \%$ \\
\hline $4 \mathrm{~F}$ & Petrika Thëngjilli, Fatmira Rama, Valentina Duka & $\begin{array}{l}\text { History 9: for the ninth grade of the nine } \\
\text { years school }\end{array}$ & 2009 & 14 & 58 & 2 & $3 \%$ \\
\hline 5 & Menduh Dërguti, Sonila Boçi, Ledia Dushku & $\begin{array}{l}\text { History 9: for the ninth grade of the nine } \\
\text { years school }\end{array}$ & 2009 & 14 & 57 & 2 & $4 \%$ \\
\hline 6 & Bernard Zotaj, Marenglen Kasmi & $\begin{array}{l}\text { History of Albanian people: for the ninth } \\
\text { grade of the nine years school }\end{array}$ & 2012 & 14 & 57 & 2 & $4 \%$ \\
\hline & $\begin{array}{l}\text { Petrika Thëngjilli, Fatmira Rama, Ajet Shahu, } \\
\text { Etleva Nita }\end{array}$ & $\begin{array}{l}\text { History 9: for the ninth grade of the nine } \\
\text { years school }\end{array}$ & 2012 & 14 & 58 & 2 & $3 \%$ \\
\hline & $\begin{array}{l}\text { Muzafer Korkuti, Petrika Thëngjilli, Gamend } \\
\text { Shpuza, Fatmira Rama, Xhelal Gjeçovi, Dilaver } \\
\text { Sadikaj, Ana Lalaj }\end{array}$ & $\begin{array}{l}\text { History of Albanian people: for the fourth } \\
\text { grade of the secondary school }\end{array}$ & 1999 & 22 & 93 & 0 & $0 \%$ \\
\hline & $\begin{array}{l}\text { Prof. Dr. Beqir Meta, Prof. Dr. Muharrem } \\
\text { Dezhgiu, Xhevair Lleshi }\end{array}$ & $\begin{array}{l}\text { History of Albanian people 12: for secondary } \\
\text { school. Social and general profile. }\end{array}$ & 2009 & 22 & 92 & 3 & $3 \%$ \\
\hline & $\begin{array}{l}\text { Muzafer Korkuti, Petrika Thëngjilli, Gazmend } \\
\text { Shpuza, Fatmira Rama, Xhelal Gjeçovi, Ana Lalaj }\end{array}$ & $\begin{array}{l}\text { History 4: social profile. For the twelfth } \\
\text { grade of the profiled secondary education }\end{array}$ & 2010 & 22 & 92 & 3 & $3 \%$ \\
\hline $11 \mid$ & $\begin{array}{l}\text { Petrika Thëngjilli, Fatmira Rama, Ajet Shahu, } \\
\text { Lorenc Bejko, Liliana Guga }\end{array}$ & $\begin{array}{l}\text { History of Albanians XII: for the twelfth } \\
\text { grade of the general secondary education }\end{array}$ & 2011 & 8 & 48 & 3 & $6 \%$ \\
\hline 12 & $\begin{array}{l}\text { Akademik Beqir Meta, Prof. Dr. Muharrem } \\
\text { Dezhgiu, Dr. Bedri Kola, Xhevair Lleshi }\end{array}$ & $\begin{array}{l}\text { History of Albanians 12: for the twelfth } \\
\text { grade of the secondary education }\end{array}$ & 2011 & 8 & 48 & 3 & $6 \%$ \\
\hline & $\begin{array}{l}\text { Menduh Dërguti, Ferit Duka, Ledia Dushku, } \\
\text { Sonila Boci }\end{array}$ & $\begin{array}{l}\text { History of Albanians 12: for the twelfth } \\
\text { grade of the secondary school }\end{array}$ & 2014 & 8 & 46 & 2 & $4 \%$ \\
\hline
\end{tabular}




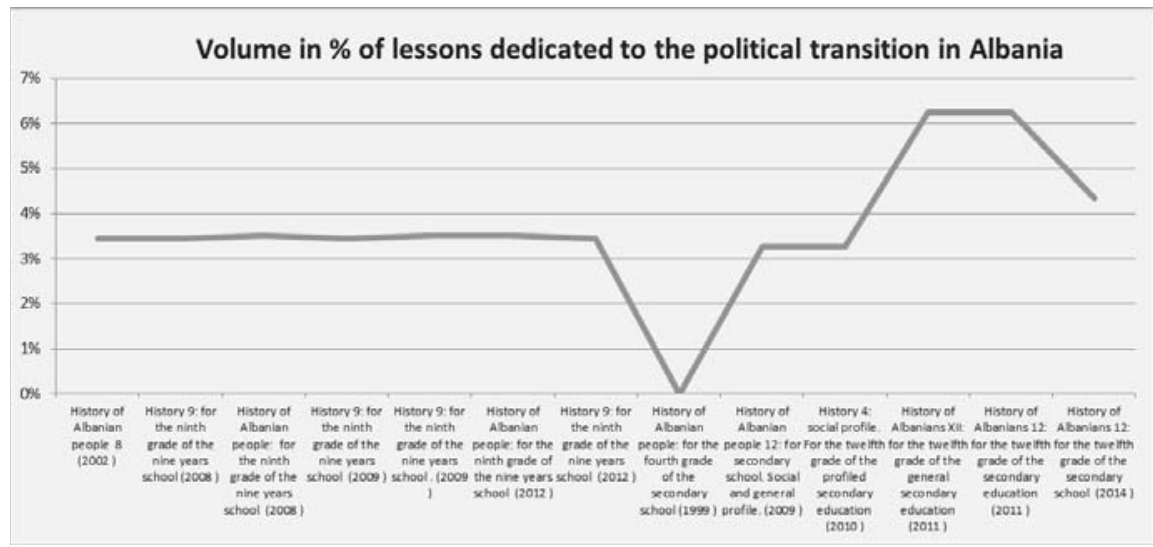

\section{Graph 1:}

This change in the timeline of the teaching material shows that "history is in a process of continuous renovation and expansion because past events as well as the ones of the later eras and their new understandings, makes it necessary that every generation writes its own history anew". Thus, "history as a discipline is open to the future". (Höflechner, Hoxha \& Gurakuqi, 2004: 20) In this context, the reconstruction of history remains unfinished, because it is impossible to highlight all relations and detail all meanings in the historical material (Aron, 2005: 168).

\section{A Discourse Analysis of the Political Transition in Albania in the Early 1990s as Presented in History Textbooks}

Discourse analysis implies not only the description and the interpretation of contents and topics of specific discourse and the investigation of the discursive strategies, but also the examination of the linguistic means (as types) and the particular context-dependent linguistic realizations (Reisigl \& Wodak, 2001: 93). The approach of the historical discourse will dominate the analyses of the change of the political systems in Albania in history textbooks of primary and secondary education. As an event that belongs to the contemporary period, it faces with the difficulty of being written objectively. Actual history requires a certain time to have a full and impartial understanding to the events and that its characters alive manage to overcome the political passions, which by interfering with the interpretation of the historical events, make them biased (Kuçaj, 2009: 3). Consequently, it is needed a time distance from the events (Mile, 2009: 6) to get closer to the historical truth, that means "judgment and criticism altogether on all sides of a given argument" (Çaushi, 2003: 11). So the historian should be characterized by the historical impartiality, an honest submission to the truth (Bloch, 2003: 145). Therefore, achieving scientific objectivity in history "requires a description or analysis of a set of events to be seen as object and not influenced by the subject". (Sinani, 1999: 181)

This process of interpretation of history aims to avoid the confounding between memory and history, which is present in the treatment of the contemporary period. According to French historian Pierre Nora, "memory is always in evolution, open to the dialectic of memory and forgetfulness, unconscious to its deformations, fragile towards instrumentalisation and manipulation and able to long sleep and unexpected awakenings. But history represents the problematic reconstruction and always incomplete of what is not. It requires analysis and critical discourse. History doubts on memory and its real mission is to remove and deconstruct the memory". (Lubonja, 2007: 7) This is the big challenge of textbooks authors of history in the post-communist Albania.

The crisis and the decline of party state system is described in the history books by the single thought, not historical multi-perspective, which represents the historical phenomena diversified (Fuga, 2009: 28). The collapse of the socialist regime appears as a result of the loss of legitimacy of the ruling government based on Marxist-Leninist ideology, referring to the lack of the socio-economic progress. In one textbook is mentioned that: "Ramiz Alia and party propaganda tried to cover the roots of the crisis, explaining the great difficulties with bad weather, enemies' sabotage and the global energy crisis, even making comics such as taking a FAO price for feeding the people, which was considered by the public opinion as a mockery and bitter irony for his suffering and misery. Other negative phenomena, that were kept hidden, 
were the rise in the unemployment rates in the cities, the increased acts of hooliganism, theft and crime in general. The Albanian society was plunged into a deep economic backwardness and political and spiritual depression". (Meta, Dezhgiu, Lleshi, 2009: 343-344)

This narrative approach prevails in the writing of history textbooks, which beyond the simplified narration "must find new ways to reconstruct not only the social and economic experience, but also the thought, the created values and the views of the social group" (Egro, 2007: 127). The descriptive approach of treating the historical events of '90s in Albania is completed with the synchronic analogy method, which corresponds to "the comparison of the two historical problems that are simultaneous, but belong to different spaces, peoples and cultures" (Mema, 2005: 16). As it is written in one textbook: "While Western Europe was reborn and was consolidating the welfare state, which managed to provide sufficient food and shelter for all categories of the population, that constituted the greatest social progress throughout the many centuries, Albania, at the end of 1980s, was seriously facing with mass famine and a standard of living nearly misery. More than $60 \%$ of the population lived below the poverty level. This was the big difference compared to the East and West of the 45 years of the communist regime". (Meta, Dezhgiu, Lleshi, 2009: 344)

The deepening of the general crisis dictated the Albanian government to emphasize the democratic elements of its ideology. The President Alia was forced to make a first step towards reform, which were superficial, with the intention of changing the form, but not the content of the regime. The textbook authors have written: "In the first half of 1989, it was launched a range of other political, economic and social measures. So they removed some laws that promoted class struggle, as the ban on deportation for agitation and propaganda, the release and the rehabilitation of prisoners of conscience, the abolition of the death penalty for escape from the country. Also, certain international standards were adopted in the field of human rights, such as the freedom of religion, the establishment of the institution of advocacy, which did not exist till that time. A step forward was the legal recognition of the plurality of opinions in the official press etc." (Korkuti, et.al., 2010: 295) "In the economic field, it was undertaken a "new economic mechanism". This measure aimed to finish highly centralized system of economic management. This mechanism essentially sought to replace the administrative-command methods with economic management methods, introducing elements of self-financing to economic enterprises. At the same time, it paved the way for the private sector in the field of handicrafts and trade and economic cooperation with the outside world. For that reason, they abolished the constitutional provisions that prohibited credit and the penetration of foreign capital". (Korkuti, et. al., 1999: 322)

The efforts to reform the system didn't meet the expectations of different social strata. They were under the influence of "the developments in communist East European countries, which led to the shock of the totalitarian regimes. On the political scene, in these countries came out political parties, organizations, forums, emblems and programs, demanding the overthrow of the communist regimes. Pluralist elections, which took place in some of these countries, were won by the right and anti-communist political forces" (Korkuti, et. al., 2010: 295). The successful democratization in a country spread like a "contagion" in the other countries of the communist bloc. The avalanche or domino effect proved the success of democratic revolutions in the Eastern European countries, where a significant role played the external factors, such as the US mission for the spread of democratic values, the impact of the CSCE to liberalize and open the Albanian society and the Gorbachev reforms in the Soviet Union that helped the collapse of the communist regimes in the eastern bloc (Luku, 2013: 46).

The wave of democratization in the Eastern Europe and the power manoeuvres undertaking half-done reforms, aimed more the propaganda effect rather than improving the system worsened the overall situation in the country. Thus began the first open and organized operations against the communist regime. "On January 14, 1990, in Shkodra, there were attempts to topple the statue of Stalin. On 26 March 1990, an anti-communist demonstration was organized in Kavaja, which was suppressed ruthlessly by the police. On July 2, 1990, a group of people sought asylum in German, Italian, French embassies etc. in Tirana. The event attracted the attention of the international opinion, which put pressure on the government to leave the country" (Dërguti, Boçi \& Dushku, 2009: 139-140). The aforementioned paragraph shows the main problem of history textbooks for primary and secondary education, which does not respect the historical relationship between content and interpretive ability. Students are overloaded with events inventory, dates and names, while the learning material does not focuses on the creation of skills to select and elaborate information, in order to prepare students to analyse the historical events (Shehu, 2009: 15).

According to a historicist group, the purpose of history is not to count just facts, but try to present them in a causal connection, being interested in the formulation of the historical laws. The initial conditions usually are estimated as the cause of the event in question and the prognosis as a result. Thus the task of the historian is to highlight the causes and identify the range of consequences. This analysis is observed in the examination of the anti-communist demonstrations in Albania. In one textbook is written: "The events of embassies triggered a chain reaction across the country. The protests 
against the communist regime grew and became more effective. The peak came with the Student Movement of December 1990. Students and professors of the University of Tirana asked for the democratization of the economic and political life of Albania. Faced openly with the popular discontent, the economic difficulties and the international pressure, the communist regime was forced to withdraw. In a meeting, he had with students on December 11, $1990 \mathrm{R}$. Alia accepted the legalization of political pluralism. Immediately after this decision, on December 12, 1990, a group of students, professors of the UT and intellectuals, founded the Democratic Party" (Thëngjilli, Rama \& Duka, 2009: 148149).

The authors continue describing that "The new party approved its program which provided political pluralism, economic reforms toward a market economy, check and balance system and guarantee of fundamental freedoms and human rights in conformity with the European standards" (Korkuti, Gjeçovi \& Gani, 2008: 187). "This historic event was met with great enthusiasm in the country. The anti-communist movement took legal forms and its main slogan was "Let us make Albania like Europe"'" (Meta, et. al., 2011: 152). Thus, "Europe" became a main reference point, whether in a political sense, or in an economic, social, cultural or intellectual context. Such a widespread tendency was embraced by the Albanian historians in order to build a new, post-socialist identity ((Re)writing history, 2004: 26).

The presentation of the historical facts and events in the history textbooks is characterized by the application of the chronological criteria. This means that the authors are taking into account the principle of historicism, which sees the development of human society chronologically and embodied in concrete actions. Without the dimension of time and chronology, the discipline of history would lose its fundaments. It is not enough to respect the chronology, i.e., simply treat the process by the course of its history, but is also necessary to reveal links between events. While the notion of time is a condition of the complexity of the historical facts and events, it is the plasma where the phenomena are established and the place they are settled. (Xhelili, 2001: 29).

The textbook writers follow the chronological order when they describe the dynamics of the events after the legalization of political pluralism. "The demonstrations in support of the Democratic Party of Albania erupted across the country. There were numerous strikes, organized by the Union of Independent Trade Unions of Albania, the newly established organization. The protests aimed at removing the symbols of communism and postponing the elections for the National Assembly, that were going to be held in February 1991. The Albanian Labor Party agreed to postpone the election date, but made no concessions on the issue of the symbols of communism and especially rewriting of the figure of Enver Hoxha. In early February 1991, students and professors of the University of Tirana went on a hunger strike. Their main demand was to remove the name of Enver Hoxha from the University of Tirana. On February 20, 1991, after a superb rally, the people of Tirana toppled the dictator's statue, which was in the "Skanderbeg square" (Dërguti, et.al., 2014: 143). This action was followed by the collapse of Enver Hoxha monuments in other cities of Albania.

This chronological paradigm of the historical phenomena intends that the previously acquired knowledge serve as a basis for acquiring logically the new knowledge, which can be interpreted closely related to each other (Kuri \& Gjini, 2008: 89). In this way, it is presented the reaction of the socialist government against the overthrow of the dictator busts. "The leadership of the Albanian Labour Party organized a military coup in the United School of Officers in Tirana, where a large number of students of this school and of the Military Academy threatened to attack with weapons the Radio Television and to restore forcefully the monument of E. Hoxha in the Skanderbeg square. The coup failed due to the resistance of the people of Tirana, which besieged the United School and didn't allow its military officers to go out. Meanwhile in the most backward areas were quickly organized anti rallies and were established the associations of "Enver's volunteers" to aggressively counter the democratic processes. Albania was close to a civil war. In these circumstances, the government of Adil Çarçani resigned and, on February 22, was created a temporary cabinet headed by the Prime Minister Fatos Nano, as well as a Presidential Council under the direction of R. Alia. Whiles, the election campaign was announced" (Meta, Dezhgiu, Lleshi, 2009: 348).

The recognition of this historical past does not always result in the expansion of the objective knowledge in a narrow sense, but often achieving a higher level of thinking in discussion and problem solving (Höflechner, Hoxha \& Gurakuqi, 2004: 21). The historian selects between events and characters because he believes that they have had some special "influence", "power" or "importance", not disconnected from their characteristics of time and space (Berlin, 2003: 182). Such an attitude is observed in the analysis of the implications of the first multiparty elections in Albania, held on March 31, 1991, which were won by the Albanian Labour Party, providing about $68 \%$ of the seats in the National Assembly. It is written in a history textbook that: "Its victory in the elections caused disappointment in the major cities, especially to the student youth. The result of the anger was also the event of 2 April 1991, where the people of Shkodra demonstrated peacefully. In this demonstration 4 youths were killed by the police, among them Arben Broci, whose murder strained more the political situation in the country" (Meta, et. al., 2008: 125). 
The interpretation of historical events requires the use of an appropriate language, to be able to draw precisely the contours of the facts, while maintaining the flexibility needed to adapt more and more the discoveries, so a language free of ambiguity, to approach the historical objectivity (Bloch, 2003: 164). These efforts are noted in addressing the political developments in Albania until the establishment of the first democratic government. The authors of one textbook have written: "The main political objective of the opposition was the overthrow of the communist government and the early elections. With its proposal, on April 29, 1991, the parliament abolished the constitution of 1976 and passed the law "On the main constitutional provisions". This law had the value of an interim constitution. It established the basic rules that allowed the normal government processes. But Nano's government was faced with the increasing economic difficulties. Extreme poverty and the country was again in crisis. The situation was further worsened by strikes of the trade unions for better conditions and wages. In these circumstances, the government of F. Nano resigned. To resolve the crisis, the political parties formed an interim government with a pluralistic composition called the Government of National Stability, under the direction of Prime Minister Ylli Bufi" (Thëngjilli, et.al., 2011: 166-167). "His government reduced somehow the political tensions, but it did not succeed in advancing the political and economic reforms and it fell, in December 1991, because of the withdrawal of the ministers of the Democratic Party. Albania, on the brink of starvation, was saved as a result of a great assistance of the Western countries, first of all of the Italian government, which successfully hosted the historic relief operation, codenamed "Pelican". In January 1992, it was established a technical government headed by Vilson Ahmeti, which led the country until the new early elections of 22 March 1992" (Meta, et. al., 2011: 155).

As noted in the above paragraph, the main paradigm in the learning materials remains that of political history based on the positivist belief that documented "facts" will reveal the truth. Thus, the history of the nation is written as a teleological sequence of significant events. The continuing dominance of political history is certainly also influenced by the contemporary experience of the historians that "politics matter" ((Re)writing history, 2004: 18).

Moreover, the teaching materials are dominated by the descriptive method of the historical writing, which brings about monotony in the treatment of various historical topics, even a lack of insight into the problems of particular importance. Anachronistic narrative in the textbooks is identified more with its didactic dimension rather than the scientific one. This pattern is used in the presentation of the electoral campaign and the confrontation of the political parties' programs, too. The elections held on March 22, 1992 ended with the victory of the Democratic Party, which provided 2/3 of the seats in the parliament. "The country's President was elected Sali Berisha. Aleksander Meksi was appointed as Prime Minister. The parliament passed laws that enabled the realization of economic reforms. They consisted in the establishment of a free market economy, the beginning of privatizations, the building and consolidation of new democratic institutions etc." (Zotaj \& Kasmi, 2012: 143)

The authors argue that Albania's foreign policy was focused on the cooperation and integration in the Euro-Atlantic structures. "The countries of the EU and the US, in the early '90s, offered Albania emergency food aid, technical and legal assistance. Later, there were signed a series of political, economic, military, scientific and cultural agreements. Albania's European integration is a multifaceted and long-term process, which involves the development of a democratic society, legislation and institutions, development of the market economy, national and regional security policy. After 1990, Albania has made some important progress towards the Euro-Atlantic integration" (Korkuti, et. al., 2010: 304).

The presentation of political system change, in the early $90 \mathrm{~s}$, in history textbooks for primary and secondary education in Albania, is based on the psychological characteristics of the school age and their level of formation. The historical concepts reflect a gradual increase of knowledge from one cycle to another (Xhelili, 2001: 33). The language used in the coverage of topics is concise and in compliance with the relevant historical terminology. The teaching material adheres to the main didactic demand of pedagogical apparatus. It is completed with the inclusion of visual sources, such as: photos, sketches etc., that serve more to illustrate the knowledge presented in the text rather than as additional information (Kuri \& Gjini, 2008: 94-95).

The examination in the history textbooks of the political developments in Albania, in relation to the collapse of the socialist regime and the establishment of a democratic system, carries special importance to create the intellectual skills to students to critically analyse and interpret the historical phenomenon and provide them with the right perception tools of the democratic transformations in the Albanian society, as well as the proper evaluation of the challenge of overcoming the political transition on the path to integration into the European Union.

\section{Conclusions}

The presentation of the change of the political system in Albania, in the early '90s, occupies a significant place in the history textbooks of primary and secondary education, particularly after the implementation of the altered text reform. It is 
examined in respect to the scientific criteria of the right proportion between the historical periods covered in the teaching materials.

The coverage of the political transition in the Albanian society in history textbooks is characterized by:

1. the prevalence of the descriptive method in presenting the political developments in Albania, the crisis and the fall of the socialist regime until the formation of the democratic government, under the Prime Minister Aleksander Meksi. The facts and the historical events, such as: the deepening of economic and social difficulties, the partial reforms of the party-state to improve the situation, the demonstrations against the communist regime, the student movement and the institutionalisation of political pluralism, the first multiparty elections of 31 March 1991 and the political situation until coming to power of the Democratic Party are described in accordance with the chronological criteria.

2. the disproportion between the historical content and the interpretive skills in general and the reflection of the period of political system change in particular. In history textbooks for primary and secondary education dominates the informative material, given in the form of descriptions, illustrations, examples and facts, rather than the forming one, characterized by the provision of the historical concepts, laws and generalizations to the relevant events.

3. the presence of the necessary pedagogical apparatus, which refers to the language and the overall structure of the educational material on the progress of establishing a democratic system in Albania. It is completed with visual sources that serve more to illustrate rather than add the objective knowledge.

The study of the political transition period in Albania, in the early 90s, is of great importance to develop the analytical and the critical thinking skills in students and to provide them with the right tools of evaluation of these historical events, which marked a significant turning point on the path towards the Euro-Atlantic structures of the Albanian state.

\section{References}

Aron, R. (2005) The opium of the intellectuals. Tiranë: Dituria

Balkan Colleges Foundation (1998). The Image of the Other: Analysis of the High-School Textbooks in History from the Balkan Countries; a research project. Sofia: Balkan Colleges Foundation

Berlin, I. (2003). Four essays on liberty. Tiranë: Onufri

Bloch, M. (2003). The historian's craft. Tiranë: Shtëpia e Librit dhe e Komunikimit

Çaushi, I. (2003). The methodology of history. Tiranë: SHBLU

Dërguti, M., Boçi, S. \& Dushku, L. (2009). History 9: for the ninth grade of the 9-years school. Tiranë: Albas

Dërguti, M., Duka, F., Dushku, L. \& Boci, S. (2014). History of Albanians 12: for twelfth grade of the high school. Tiranë: Albas

Egro, D. (2007). History and ideology. A critical approach of the Ottoman studies in modern Albanian historiography (from the second half of the XIX century until today). Tiranë: Instituti i Historisë

Fuga, A. (2009). "Political lightning on a textbook", Standard, Saturday, 26 September 2009

History education and post-conflict reconciliation: reconsidering joint textbook projects (2013). Ed. by K. V. Korostelina and S. Lässig with S. Ihrig, London: Routledge

Höflechner, W., Hoxha, G. \& Gurakuqi, R. (2004). Introduction to the study of history. Shkodër: Phoenix Shkodra

Huntington, S. (2011). The Third Wave: Democratization in the Late 20th Century. Tiranë: AllS

Korkuti, M., Thëngjilli, P., Shpuza, G., Rama, F., Gjeçovi, Xh., Sadikaj, D. \& Lalaj, A. (1999) History of the Albanian people: for the fourth grade of the secondary school. Tiranë: SHBLSH

Korkuti, M., Thëngjilli, P., Shpuza, G., Rama, F., Gjeçovi, Xh., Shahu, A. \& Lalaj, A. (2002) History of Albanian people 8. Tiranë: SHBLSH

Korkuti, M., Gjeçovi, Xh. \& Gani, A. (2008). History 9: for the ninth grade of the 9 years school. Tiranë: Morava

Korkuti, M., Thëngjilli, P., Shpuza, G., Rama, F., Gjeçovi, Xh. \& Lalaj, A. (2010). History 4: social profile. For the twelfth grade of the profiled secondary school. Tiranë: Pegi

Kuçaj, K. (2009). "Milo: The book, like the bulletin released by the offices of the Democratic Party", Korrieri, Thursday, 24 September 2009

Kuri, V. \& Gjini, R. (2008). The theoretical basis and practices of learning history. Tiranë: SHBLU

Lubonja, F. (2007). "Memory and history". Korrieri. - No. 259, Thursday, 25 September 2007

Luku, E. (2013). "Aspects of the political transition in Albania (1990-1992)", Social Studies, vol. 7, no. 2, 2013, Tiranë: AIS

Mema, B. (2005). Knowledge of research in the field of history. Tiranë: SHBLU

Meta, B., Dezhgiu, M., Kola, B. \& Lleshi, Xh. (2008). History of the Albanian people: for the ninth grade of the middle school. Tiranë: Uegen

Meta, B., Dezhgiu, M. \& Lleshi, Xh. (2009). History of the Albanian people 12. Tiranë: Uegen

Meta, B., Dezhgiu, M., Kola, B \& Lleshi, Xh. (2011). History of Albanians 12: for the twelfth grade. Tiranë: Uegen

Mile, A. (2009). "Arben Puto: It takes time to analyze '97". Panorama, Tuesday, 29 September 2009 
Minoski, Y. (2001). "The historical personalities of the neighbors in the Elementary and Secondary Education History Textbooks of the Former Yugoslav Republic of Macedonia", The image of "the other"/ neighbor in the school textbooks of the Balkan countries: proceedings of the International Conference, Thessaloniki, 16-18 October 1998. Ed. by Panos. D. Xochellis and Fotini L. Toloudi, Athens: Dardanos

Popper, K. (2003). The poverty of historicism. Tiranë: Onufri

Reisigl, M. \& Wodak, R. (2001). "The discourse-historical approach", Methods of Critical Discourse Analysis. London: Sage Publications Ltd.

Repoussi, M. and Tutiaux-Guillon, N. (2010). "New trends in History Textbook Research: Issues and Methodologies toward a School Historiography", in Journal of Educational Media, Memory and Society, Volume 2, Issue 1, Spring 2010

(Re)writing history. Historiography in Southeast Europe after Socialism (2004). Edited by Ulf Brunnbauer, Münster

Simoska, E. (2001). "General problems in the History textbooks of the Balkans", Teaching the History of Southeastern Europe, Center for Democracy and Reconciliation in southeast Europe, Thessaloniki

Sinani, Gj. (1999). Introduction to the philosophy of history. Tiranë: SHBLU

Shehu, H. A. (2009). "History in the optic of pseudoscientists", Shekulli, Tuesday, 6 October 2009

Thëngjilli, P., Rama, F. \& Duka, V. (2009). History 9: for the ninth grade of the middle school. Tiranë: Ideart

Thëngjilli, P., Rama, F., Shahu, A., Bejko, L. \& Guga, L. (2011). History of the Albanians XIl: for twelfth grade of the general secondary school. Tiranë: Pegi

Xhelili, Q. (2001). Didactics of history. Tiranë: SHBLU

Zotaj, B. \& Kasmi, M. (2012). History of the Albanian people: for the ninth grade of the middle school. Tiranë: Filara 